\title{
Editorial Foreword 74.3 (August 2015)
}

\section{Our Cover}

This illustration was featured in the catalogue Shinpo Isseiki Shikago Bankoku Hakurankai: Manshū shuppin hōkokusho (A Century of Progress World Exhibition in Chicago: A report of Manchurian exhibits). Kari Shepherdson-Scott, who provided the image for her article in this issue, tells us, "I came across it years ago while conducting research on Japanese-sponsored Manchuria exhibitions. I was immediately struck by the modest scale of the Manchuria pavilion and the way it stylistically resonated with the Japan pavilion next to it. Given the contentious international debates surrounding Japanese military activities in northeast Asia since the Manchurian Incident in 1931, the little pavilion begged further investigation." The catalogue, which is quite rare, is held in the Yale University Library collection.

\section{IN THIS Issue}

This issue of the Journal has five pieces that deal in radically different ways with a single broad subject: Japanese military incursions into neighboring countries between the early 1930s and the end of World War II in 1945. These essays, three very short ones that were commissioned as a set plus two long ones that came independently, intersect and overlap in intriguing ways. They also have a special topicality due to this being the year that the seventieth anniversary of Japan's surrender is being marked. Before saying any more about them, however, I want to stress that, despite the intersections between that quintet of essays, the hallmark of this issue remains-like most recent ones - the wide variety of periods, disciplines, and parts of Asia represented within it.

\section{Asia Beyond the Headlines}

The trio of essays opening this issue are interwoven into a single piece: a tripartite look at the seventieth anniversary of Japan's surrender at the close of World War II. Its component parts are short essays by leading historians of East Asia: CAROL GLUCK (Japan), Rana Mitter (China), and Charles K. Armstrong (Korea). These scholars, responding to questions that I posed to them, look at the different ways that dates associated with the war's end in 1945 have been marked in Asia in the past and how they are likely to be marked this August and September. They also discuss how the year 1945 more generally has been seen, thought about, and discussed in different parts of East Asia. Historical anniversaries tend to be moments to reflect on continuity and rupture, 
so it seems fitting to note how this opening set of short pieces both fits in with and breaks from things that the Journal of Asian Studies has done in the past.

It carries forward the recently launched "Asia Beyond the Headlines" initiative, and it is the second contribution to this genre thus far to be framed around answers to questions, the first having been a discussion of Japanese and Korean elections moderated by David Kang, who was then a JAS associate editor. The specific form, though, is novel, as that earlier question-and-answer-based "Asia Beyond the Headlines" was made up of much shorter replies to a series of queries, while Gluck, Mitter, and Armstrong present tightly constructed miniature essays inspired by a set of queries. The Journal has also never, as far as I know, brought together a series of ruminations from different parts of Asia on a single historical anniversary.

Thought about more broadly, though, there is a sense of return to the beginning of the periodical's history in this exchange. This is because the very first article in the inaugural issue of the Far Eastern Quarterly, as the Journal of Asian Studies was known in its initial years, was an essay on "The New Order in East Asia" by Kenneth Colegrove (vol. 1, pp. 5-24). Published in November 1941, just before Pearl Harbor, this article sought to place the Japanese invasions and official government statements attempting to justify those actions into historical context. It also looked forward, suggesting in its final sentence that given the extent to which "the holy war in China is now waged on behalf of the New Order ... the failure of the Japanese attempt to conquer China will point to the collapse of the New Order in East Asia."

The "To Our Readers" section that preceded Colegrove's essay included lines that also suggest a mix of continuity and change in recent developments at the JAS as a whole. "A glance at the contents of this first issue of the FAR EASTERN QUARTERLY will, we believe, quickly disclose," it began, a desire to fill the "gap existing between journals dealing with contemporaneous opinions and events, and the more specialized professional and academic publications." Its goal was to "provide a medium of publication for the increasing number of specialists in the Far Eastern field," while presenting "material in such manner that it will be of utility and interest to the general reader."

\section{Research Articles}

The first two essays in this section each deal in part with the short-lived state of Manchukuo and hence also touch upon Japanese military actions and empire-expanding efforts. The first of these, Kari Shepherdson-scott's "Conflicting Politics and Contesting Borders: Exhibiting (Japanese) Manchuria at the Chicago World's Fair, 1933-34," examines a pavilion at the A Century of Progress Exposition that was "small" but "bore immense political weight," since its very existence testified to how determined Japan was to try to persuade international opinion to see its actions in northeast China as legitimate. Chigusa Yamaura's "From Manchukuo to Marriage: Localizing Contemporary Cross-Border Marriages between Japan and Northeast China," as its title suggests, is a work about the present, but one in which legacies of Japanese migration to and conquest of Manchuria figure in complex ways.

Two essays that capture well the issue's diversity are "The Dog-Eared Dictionary: Human-Animal Alliance in Chinese Civilization," which is the work of language and 
culture specialist Claire Huot, and "Demonic Violence and Moral Panic in Postwar Sri Lanka: Explaining the Grease Devil Crisis," whose author, Rajesh Venugopal, is a scholar of international development. These articles examine canine terms and symbolism over millennia in East Asia's largest country, in the first case, and recent rumors in a South Asian island nation, in the second. The former draws on an etymological work from the second century, alludes to an imaginative work by Jorge Luis Borges, and brings in findings from archaeology and zoology as well as comparative linguistics to trace "the destiny of the dog in semantic and graphic terms" in China. The latter makes use of interviews and news reports, and plumbs the scholarship in fields such as psychology and comparative religion, in an effort to come to terms with a "shadowy and ambiguous figure who inhabits the cosmos of rural and small-town Sri Lanka.” This figure seems to be a quite recent invention, as this "grease devil" does not get a mention in "any of the studies and compendia of Sinhalese demonology" published in the nineteenth and twentieth centuries.

The remaining three research articles — studies of Indonesia's forests, Korean women's writings, and media in Mumbai, respectively—similarly showcase the rich diversity of Asian studies at the current moment. The first of these, PAUl K. Gellert and Andiko's "The Quest for Legal Certainty and the Reorganization of Power: Struggles over Forest Law, Permits and Rights in Indonesia," is the joint effort of a sociologist and a legal scholar and past director of an Indonesian NGO. The second of them, Jisoo M. KIm's "Women's Legal Voice: Language, Power, and Gender Performativity in Late Chosǒn Korea," begins with an analysis of an eighteenth-century petition that a slave made to a king. The third, Patrick Eisenlohr's "Media, Citizenship, and Religious Mobilization: The Muharram Awareness Campaign in Mumbai," is based on ethnographic work among "Shi ite activists as well as ordinary Shi ite Muslims in everyday settings" in an Indian city.

\section{Book Review Essay}

Adding further to the diversity of the issue are the usual mix of book reviews and an unusually extensive review essay by SUDIPTA SEN on "Liberalism and the British Empire in India" that focuses on four recent books. Sen links together the quartet of publications, including a major work by the late C. A. Bayly, saying they offer a sophisticated survey of the ways that the "history of political rights in India" has been and will remain "tied inextricably to the history of empire."

\section{Forthcoming Articles in JAS 74.4 (November 2015)}

Premonitions of the Past

Mrinalini Sinha

Juliet Got It Wrong: Conversion and the Politics of Naming in Kumaon, ca. 1850-1930 SANJAY JOSHI 
The Long Struggle: Enlightenment, Counter-Enlightenment, and the Importance of Intellectuals in Democratization

Daniel Chirot

Democracy with Asian Characteristics

MarK R. ThOMPSON

The Surprising Democratic Behemoth: Indonesia in Comparative Asian Perspective EDWARD ASPINALL

The Future of Chinese Democracy

Elizabeth Perry

Development as Entangled Knot: The Case of the Slaughter Renunciation Movement in Tibet, China

KabZung GaERrang

Three Models of Welfare and Current Chinese Social Assistance: Confucian Values, Variable Application

Dorothy J. SOLINGER

Red Guards and Salary-Men: The Chinese Cultural Revolution and Comic Satire in 1960s Japan

Erik Esselstrom 